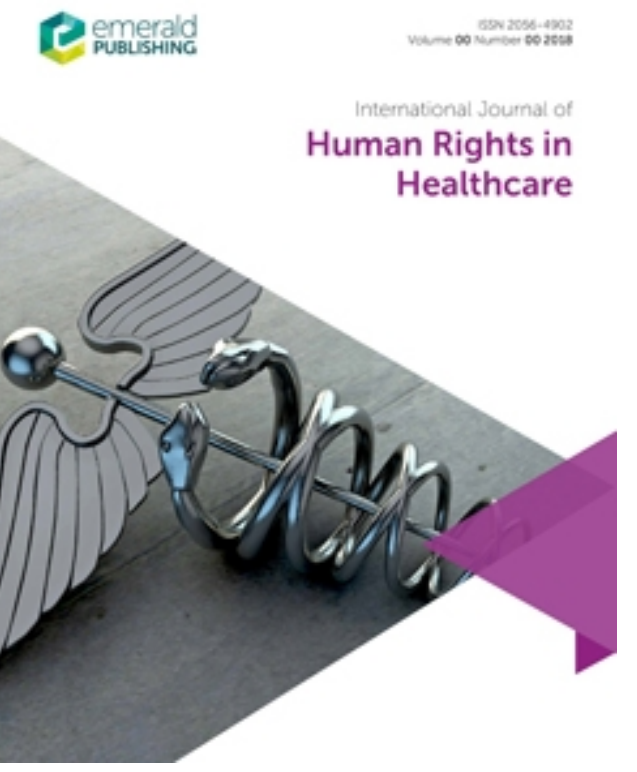

\title{
Populism, pestilence and plague in the time of Coronavirus
}

\begin{tabular}{|r|l|}
\hline Journal: & International Journal of Human Rights in Healthcare \\
\hline Manuscript ID & IJHRH-10-2020-0091.R1 \\
\hline Manuscript Type: & Viewpoint Paper \\
\hline Keywords: & $\begin{array}{l}\text { healthcare, human rights, race, Covid-19; coronavirus; right-wing } \\
\text { populism; Camus }\end{array}$ \\
\hline
\end{tabular}

\section{SCHOLARONE $^{\text {IM }}$ \\ Manuscripts}




\title{
Populism, pestilence and plague in the time of Coronavirus
}

\author{
Russell Mannion $^{1 *}$ and Ewen Speed ${ }^{2}$
}

1* Corresponding author

Professor Russell Mannion

Health Services Management Centre

Park House, 40 Edgbaston Park Rd

University of Birmingham

Birmingham, B15 2RT

Email: r.mannion@bham.ac.uk

2) Dr Ewen Speed

School of Health and Human Sciences

University of Essex

Wivenhoe Park, CO4 3SQ

Email: esspeed@essex.ac.uk 


\section{Abstract}

\section{Purpose}

To explore right wing populist government responses to the coronavirus pandemic.

\section{Design/methodology/approach}

A narrative overview of right-wing populist policies and strategies which is loosely structured around fascistic themes set out in Albert Camus' allegorical novel, The Plague.

\section{Findings}

Although individual responses to the coronavirus pandemic among right-wing populists differ, they appear to coalesce around four central themes: initial denial and then mismanagement of the pandemic; the disease being framed as primarily an economic rather than a public health crisis; a contempt for scientific and professional expertise; and the 'othering' of marginal groups for political ends. Populist responses to the pandemic have given rise to increased levels of xenophobia, the violation of human rights and the denigration of scientific expertise.

\section{Research limitations}

This is a narrative overview from a personal viewpoint.

\section{Originality}

Drawing on themes in Camus' novel The Plague, this is a personal perspective on right wing populist government responses to the coronavirus pandemic. Populist responses to the pandemic have given rise to increased levels of intolerance and xenophobia and the violation of human rights and civil liberties.

\section{Keywords}

COVID-19, coronavirus, right wing populism, fascism, racism, human rights, Camus 


\section{A story for our times}

Death, human suffering and social collapse wrought by plagues have throughout history been the morbid inspiration for great writers, from Giovanni Boccaccio's The Decameron published in the middle ages, to more recently Blindness by Jose Saramago. Of this genre, Albert Camus' The Plague (Camus, 2012) - the novel that more than any other work earned him the Nobel prize for literature, is the most acclaimed and widely read. Published over 70 years ago, the novel is a fictional account of the outbreak of a bubonic-like plague or "pestilence" which seizes the Algerian town of Oran. The novel recounts the physical and moral degradation of the city's inhabitants and the personal and collective ethical dilemmas this raises. Rereading The Plague during the coronavirus pandemic is an unsettling experience. Unrelentingly bleak as it is, the themes explored feel uncannily prescient. The novel lends itself to multiple interpretations. On one plane, it is a straightforward narrative, immediately relevant to current times with its language of quarantines, physical distancing, faulty government responses, supply shortages, experimental vaccine trials and overburdened care givers. There is even mention of 'flattening of curves' It can also be read as an absurdist drama on the futility of human endeavor against the vicissitudes of nature: the plague kills indiscriminately and who dies and who survives is completely random. A third interpretation is that it is a novel shaped by Camus' own war time experiences - a transparent allegory to the Nazi occupation of France. On this reading the novel suggests that it is the ideological virus of Fascism (the so-called brown plague) which, in the face of timid politicians and an apathic public, can quickly spreads to infect the whole body politic. In a letter to his friend Roland Barthes, Camus explains "The Plague should be read on several levels; but nevertheless its obvious content is the struggle of the European Resistance against Nazism... .In a sense it is more than a chronicle of the Resistance. But it most certainly is not less."

The Plague as metaphor for fascism and the excesses of state authoritarianism is more relevant than ever in a time of the worldwide coronavirus pandemic. There are striking parallels with the rise to power of right-wing populist 'strongmen' around the globe and the way in which populist ideology and programmatic agendas have taken root and shaped national responses in (mis) managing the current pandemic. The global upsurge in populism can be understood as a symptom of the wider crisis of legitimation affecting liberal democracies. The populist art of governance is based on a 'moral monopoly of representation' with populist leaders claiming to 
speak on behalf of 'the people' against an estranged 'corrupt elite'. In so doing, sidestepping both scientific expertise and the constraints of deliberative decision making. The recent upsurge in right-wing populism around the world has close affinities with the rise of fascism in the 1930s. Indeed, the latest iteration of right-wing populism can be viewed as a reformulation of classic fascism, 'or one might argue a heir to fascism, a post-fascism for democratic times' (Finchelstein, 2017). Based on this reading what follows is a brief overview of right-wing populist responses to the pandemic which is loosely structured around fascistic themes developed by Camus in The Plague.

\section{Denial, distortion and delay}

In Camus' novel, the early signs of the plague - when rats crawl out from the sewers 'spitting blood' and die in the streets - are initially ignored and then downplayed by Oran's complacent municipal leadership, essentially as it turns out, to avoid adversely affecting the local economy. Strict sanitation measures are only enacted by the civic authorities once it becomes impossible to deny that the plague is ravaging the city and decimating the stricken inhabitants. These events in the novel clearly resonate with the slow acceptance and delayed response to the impending threat of coronavirus which has been typical of many populist leaders. In the United States, Donald Trump dismissed the virus as a 'Democratic hoax' and referred to the nation's leading infectious disease expert, Anthony Fauci, as a "little bit of an alarmist" (Yamey \& Gonsalves, 2020). In January 2020, Trump said: "We have it totally under control. It's one person coming in from China, and we have it under control. It's going to be just fine." Even into February, as the severity of the pandemic began to be realised worldwide, Trump trivialised the threat, openly stating it was like the common flu (Bump, 2020). Throughout the summer of 2020, Trump continued to hold crowded mass election rallies with little social distancing and on 2 October announced on Twitter that he, himself, had tested positive for COVID19. Then on leaving hospital on 5 October he blithely tweeted "Feeling really good! Don't be afraid of COVID. Don't let it dominate your life". This was despite the US at the time having more than 200,000 deaths from COVID-19. When Trump lost the presidential election in November 2020, he disputed the outcome and refused to allow the team of the president elect to access crucial information from the Centers for Disease Control and Prevention and Food and Drug Administration which could have helped to reduce the spread of the virus. 
Meanwhile in Brazil, the populist leader Jair Bolsonaro stated that flu had killed more people in the country than COVID-19 (Pfrimer \& Barbosa, 2020). In July, he appeared live on television wearing a mask and announced that he had tested positive for the virus, following months of flouting social distancing, refusing to wear a mask and dismissing the pandemic as a 'media trick’ (Ortega \& Orsini, 2020) . Elsewhere, Daniel Ortega in Nicaragua and Alexander Lukashenko in Belarus continued to downplay the threat of the virus and ignored expert advice on social distancing, actions that helped to facilitate spread of the virus. Similarly, the UK government initially sought to maintain business as usual (Hunter, 2020). Boris Johnson chose to ignore the gravity of the situation and refused initially to introduce lockdown measures. Johnson later tested positive for COVID-19 and spent a period in intensive care. These patterns of mismanagement by right -wing populist leaders in response to the pandemic is supported by the findings of a quantitative study on political leaders' responses to COVID-19 across 94 countries (Kavakli, 2020). The study found that governments headed by populist leaders tended to put in place fewer interventionist public health policies and strategies, (for example by responsibilising individual citizens rather than mandating a government response), and were slower to implement lockdowns at local or national levels, than non-populist ones. It is clear that many right-wing populist leaders have failed to implement a coherent public health strategy for their nations and in some cases have dismantled the very institutions designed to safeguard against major threats to public health. In the UK, the cabinet's Threats, Hazards, Resilience and Contingency Committee was disbanded by Johnson soon after being elected. Similarly, three months before the emergence of COVID-19 in the USA, Trump abolished the USAID-funded PREDICT programme, created to provide early intelligence on the possible outbreak of pandemics (McKee et al, 2020). In an attempt to distract attention from the delayed response to the seriousness of the virus, Trump blamed the WHO for their delayed reaction and stated that the United States would withdraw their funding from WHO despite praising them a month earlier (Yamey and Gonsalves, 2020).

Although Trump and Johnson have appropriated populist political tactics and styles they were elected to office as candidates of mainstream political parties in established liberal democracies. However, it is clear that right wing populist leaders in less consolidated democracies such as Viktor Orbán in Hungary, Andrej Babiš in the Czech Republic and Mateusz Morawiecki in 
Poland and have used the pandemic as a window of opportunity to erode democratic norms, violate human rights and tighten executive grip on power. The refrain being that extraordinary times require extraordinary measures. Witness how Orbán has used the coronavirus crisis to invoke extensive emergency powers and declare an open-ended state of emergency. Probably the most extreme example of a populist politician seizing on the pandemic to tighten authoritarian rule is in the Philippines, where Rodrigo Duterte issued a 'shoot to kill order to the police and military authorities for anyone found violating the curfew.

\section{Disinformation and 'Othering'}

Back in Camus' Oran, misinformation about the virus spread, with the surviving inhabitants believing that peppermint lozenges and alcohol could ward off contagion. As they struggled to stay alive, there was an increase in paranoia as people returning from quarantine set their homes alight in a desperate and mistaken attempt to combat the spread of the plague. During the current pandemic social media platforms have provided a rich ecosystem for populists to bypass the mainstream media and directly promote conspiracy theories which are completely unencumbered by facts or evidence. This strategy has resulted in a deluge of misinformation and unscientific speculations about the virus, its origin, prevention, diagnosis, and treatment. There have been claims the virus is linked to new telecommunications technology supporting $5 \mathrm{G}$ networks (Ahmed et al, 2020), and several populist politicians have promoted dangerous treatments such as injecting disinfectant and using hydroxychloroquine, as advocated by Trump and Bolsanaro (see Hatcher, 2020). Similarly, there has been marked disagreement over the wearing of face masks, with many right-wing populist politicians problematising their efficacy and pejoratively referring to them as 'muzzles' (Woods et al, 2020). that spread hate and division, and

Like the Oran authorities, populist leaders have tended to view the pandemic as a Public Relations exercise. As if speaking of Trump, Camus says in The Plague, "The most incorrigible vice being that of ignorance that fancies that it knows everything and therefore claims for itself the right to kill”. Populism thrives on crisis, even depends on fabricating a sense of a crisis by identifying 'folk devils' and creating moral panics, whereby apparent threats to collective interests are amplified through inflammatory rhetoric (Mannion and Small, 2019). Moral panics can also serve as a delusion, distracting attention from the root causes of crises. Populists cast 
crises as situations which they alone, usually in the form of a strong leader cast as saviour, have the power to resolve (Speed and Mannion, 2017). Yet the current pandemic has resulted in a curious reversal in populist responses to crises. During the current pandemic it is populists who have blamed medical experts and the media for exaggerating the crisis. Although populist leaders have certainly tried to leverage and profit from the pandemic, the crisis is performed as an economic crisis, not as a health crisis. It is apparent that nativist populism, including welfare chauvinism, by which the interests of those born in a state are protected against those of immigrants or particular minority groups, have been promoted during the current pandemic. This is because, to be effective restrictive public health measures such as lockdowns, need to apply to all groups, whereas the ideology of populism is performed through the identification of in-groups and out-groups (Speed and Mannion, 2020). Populists have therefore sought to turn the health crisis into an economic crisis in order to play to their political base: saving livelihoods rather than lives. If the crisis is perceived as a health crisis, nativist populism is rendered ineffective when a collective lockdown response is required. As lockdown conditions have eased, and as the public health crisis has apparently been superseded by the economic crisis, populist leaders have once again used the deeply racist tropes of nativism by 'othering' minority groups who have been misrepresented via populist social media as virulent carriers of the virus, rather than victims worthy of sympathy and public support. These include Mexican immigrants being blamed in the United States, Hindu nationalists scapegoating Muslims in India and indigenous communities inculpated in Brazil (McKee et al, 2020). Trump has sown division along ethnic and national lines and has repeatedly referred to the pandemic as the 'Chinese or 'Kung Flu' virus (Zeng et al, 2020). In Hungary, Orbán has referred to the pandemic and migrants as a "two-front war", further stating that 'there is a logical connection between the two, as both spread with movement'.

Back in Oran, the civic authorities initially failed to support vulnerable groups and those living in poverty are conscripted to deadly, 'essential' jobs. One of the characters in the book states that those who are forced by civic officials to undertake tasks which expose them to the virus are effectively given a death penalty. It is clear that the current pandemic is deepening health inequalities. There is a social patterning of morbidity and mortality associated with the virus which appears to be based on structural inequalities and institutional racism (see Iacobucci, 
2020; Ravi, 2020). People of colour, women, and working-class people, many of whom live in crowded conditions, have precarious employment and undertake jobs and caring roles that expose them more frequently to the virus with concomitant higher risks of infection, severe illness and death (see Iacobucci, 2020; Ravi, 2020). In the UK, the government has even been accused of censoring its own report into the disproportionate vulnerability of BAME and disadvantaged populations to the coronavirus (Moore, 2020).

\section{Anti-science and denigration of professional expertise}

All plagues involve the affected society creating an intellectual framework to make sense of the pathogen. In The Plague there is a rancorous debate over the cause of the disease and the best way to respond to the pestilence between the doctor, who subscribes to a modern, scientific approach to the disease, and the Catholic priest, who preaches that the plague is God's punishment - an act of divine retribution on the city's inhabitants brought on by sinful lifestyles. Here there are clear parrels with populist ideology which valorises common sense solutions based on personal experience and is hostile to abstract forms of scientific knowledge. In the current pandemic this is most clearly seen in relation to the development of a COVID-19 vaccine. As the virus continues to have a devastating impact across the globe an effective massproduced vaccine is generally regarded as the only feasible way out of the pandemic. However, there is a well-rehearsed right wing resistance to vaccination programmes (Speed \& Mannion, 2020). Vaccine hesitancy and right-wing populism are both characterised by an antipathy towards scientific expertise and a profound distrust in so-called medical elites. A vaccine will only control the spread of the virus if a significant proportion of the population are vaccinated and herd immunity is achieved. However, a recent survey suggests that up to half of the populations in the United States would turn down a COVID-19 (Cornwall, 2020). Indeed, crossnational research has found a highly significant positive association between the percentage of people in a country who voted for populist parties and the percentage who believe that vaccines are not important (Kennedy, 2019). Nevertheless, it is not always the case that populist politicians have rejected scientific expertise in responding to the pandemic. Citing Turkey's Erdoğan as an example, Katsambekis and Stavrakakis (2020) state that those populists who attacked 'heterodox experts' were 'driven more by their authoritarian tendencies and an 
intolerance to critique' rather than the populist tactic of polarising cultural divisions and pitting the 'people' against a perceived professional elite.

\section{Concluding remarks}

Whilst there are many similarities in the ways in which right wing populist governments and leaders have responded to the pandemic, it would be wrong to claim that they all share a common response to the greatest public health challenge of our time. Instead, there appears to have been a suite of moves and supporting tactics performed by populist governments at different junctures, tailored to local circumstances (Pavolini et al, 2018). Nevertheless, there are clear similarities, which coalesce around a number of common themes: initial denial and then mismanagement of the pathogen; the pandemic being framed as primarily an economic rather than a public health crisis; a contempt for scientific and professional expertise; and the 'othering' of marginal groups for political ends.

The final paragraph of The Plague is particularly chilling in the current context. Camus cautions that the end of the plague does not represent a definitive victory over fascism/the virus, with the warning that the pestilence is always with us:

"that the plague bacillus never dies or disappears for good; that it can lie dormant for years and years in furniture and linen-chests; that it bides its time in bedrooms, cellars, trunks, and bookshelves; and that perhaps the day would come when, for the bane and the enlightening of men, it would rouse up its rats again and send them forth to die in a happy city".

It is clear that right - wing populist leaders around the globe have mismanaged the pandemic and have used the crisis as an opportunity to fuel nativism and xenophobia, assail human rights and denigrate scientific expertise. Right-wing populism is dangerous for all our health and this insidious poison in the body politic needs to be exposed and challenged for what it is. As we emerge from the pandemic the imperative is for public health policies to continue to provide a breadth of coverage and ensure parity of access to services for all groups in society based on the application of rigorous scientific evidence. 


\section{REFERENCES}

Ahmed, W., Vidal-Alaball, J., Downing, J., \& López Seguí, F. (2020). COVID-19 and the 5G Conspiracy Theory: Social Network Analysis of Twitter Data. Journal of Medical Internet Research, 22(5), e19458. https://doi.org/10.2196/19458

Bump, P. (2020, March 24) Trump again downplays coronvirus by comparing it to the seasonal flu. It's not a fair comparison, Washington Post, https://www.washingtonpost.com/politics/2020/03/24/trump-again-downplayscoronavirus-by-comparing-it-seasonal-flu-its-not-fair-comparison/

Camus, A. (2012). The Plague. Vintage.

Cornwall, W (2020) Just 50\% of Americans plan to get a Covid-19 vaccine, Science https://www.sciencemag.org/news/2020/06/just-50-americans-plan-get-covid-19-vaccinehere-s-how-win-over-rest (accessed 14 October, 2020)

De Cleen, B., \& Speed, E. (2020). Getting the Problem Definition Right: The Radical Right, Populism, Nativism and Public Health Comment on" A Scoping Review of Populist Radical Right Parties' Influence on Welfare Policy and its Implications for Population Health in Europe". International Journal of Health Policy and Management. https://www.ijhpm.com/article_3878_0aflb839378705b1dee10ea32d62f69a.pdf

Greenhalgh, T., Schmid, M. B., Czypionka, T., Bassler, D., \& Gruer, L. (2020). Face masks for the public during the covid-19 crisis. Bmj, 369.

Finchelstein F (2017) From Fascism to Populism in History, Oakland: California UP

Hatcher, W. (2020). A Failure of Political Communication Not a Failure of Bureaucracy: The Danger of Presidential Misinformation During the COVID-19 Pandemic. The American Review of Public Administration, 50(6-7), 614-620. https://doi.org/10.1177/0275074020941734

Hunter, D. J. (2020). Covid-19 and the Stiff Upper Lip - The Pandemic Response in the United Kingdom. New England Journal of Medicine, 382(16), e31. https://doi.org/10.1056/NEJMp2005755

Iacobucci, G. (2020). Covid-19: Racism may be linked to ethnic minorities' raised death risk, says PHE. BMJ (Clinical Research Ed.), 369, m2421. https://doi.org/10.1136/bmj.m2421

Kavakli, K. C. (n.d.). Did Populist Leaders Respond to the COVID-19 Pandemic More Slowly? Evidence from a Global Sample. working paper. Milan. Boconni University.

Kennedy, J. (2019). Populist politics and vaccine hesitancy in Western Europe: an analysis of national-level data. European Journal of Public Health. 
McKee M; Gugushvil A; Koltai J; Stuckler D (2020) Are Populist Leaders Creating the Conditions for the Spread of COVID-19? Comment on "A Scoping Review of Populist Radical Right Parties' Influence on Welfare Policy and its Implications for Population Health in Europe, International Journal of Health Policy and Management. https://www.ijhpm.com/article_3856.htm

Mannion R and Small N (2019) Folk Devils, Moral Panics and New Wave Public Health, International Journal of Health Policy and Management. 8(12), 678-683.

Moore, A. (2020). Exclusive: Government censored BAME covid-risk review. Health Service Journal.

Ortega, F., \& Orsini, M. (2020). Governing COVID-19 without government in Brazil: Ignorance, neoliberal authoritarianism, and the collapse of public health leadership. Global Public Health, 15(9), 1257-1277.

Pavolini E, Kuhlmann E, Agartan TI, Burau V, Mannion R, Speed E. Healthcare governance, professions and populism: is there a relationship? an explorative comparison of five European countries. Health Policy. 2018;122(10):1140-1148

Pfrimer, M. H., \& Barbosa, R. (2020). Brazil's war on COVID-19: Crisis, not conflict—Doctors, not generals. Dialogues in Human Geography, 10(2), 137-140. https://doi.org/10.1177/2043820620924880

Ravi, K. (2020). Ethnic disparities in COVID-19 mortality: are comorbidities to blame? The Lancet, 396(10243), 22. https://doi.org/10.1016/S0140-6736(20)31423-9

Reicher, S., \& Stott, C. (2020). On order and disorder during the COVID-19 pandemic. British Journal of Social Psychology, 59(3), 694-702. https://doi.org/10.1111/bjso.12398

Saramago, J. (2013). Blindness. Houghton Mifflin Harcourt.

Speed E, Mannion R. The rise of post-truth populism in pluralist liberal democracies: challenges for health policy. Int J Health Policy Manag. 2017;6(5):249-251

Speed, E., \& Mannion, R. (2020). Populism and health policy: three international case studies of right-wing populist policy frames. Sociology of Health \& Illness.

Woods, E. T., Schertzer, R., Greenfeld, L., Hughes, C., \& Miller-Idriss, C. (2020). COVID-19, nationalism, and the politics of crisis: A scholarly exchange. Nations and Nationalism, $n / a(\mathrm{n} / \mathrm{a}) . \mathrm{https}: / /$ doi.org/10.1111/nana.12644

Yamey, G., \& Gonsalves, G. (2020). Donald Trump: a political determinant of covid-19. BMJ, 369. https://doi.org/10.1136/bmj.m1643

Zeng, G., Wang, L., \& Zhang, Z. (2020). Prejudice and xenophobia in COVID-19 research manuscripts. Nature Human Behaviour. https://doi.org/10.1038/s41562-020-00948-y 


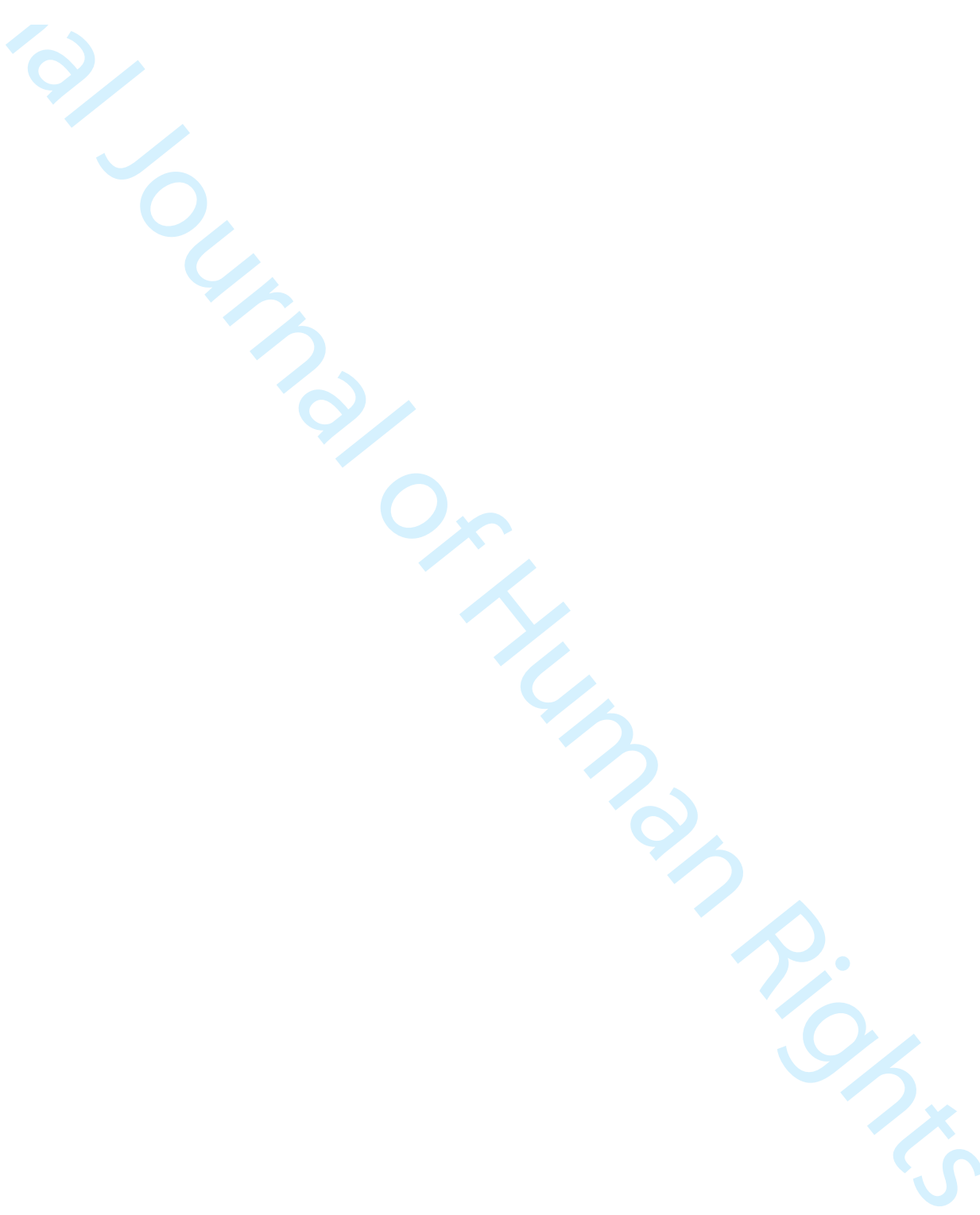

